\title{
Ichthyofauna associated with drifting floating objects in the Balearic Islands (western Mediterranean)*
}

\author{
FRANCISCO RIERA ${ }^{1}$, AMALIA GRAU ${ }^{2}$, ANTONIO M. GRAU ${ }^{3}$, ELENA PASTOR $^{1}$, \\ ANTONI QUETGLAS ${ }^{1}$ and SEBASTIÁN POU ${ }^{1}$ \\ ${ }^{1}$ Estació d’Aqüicultura. Camí del Far s/n, 07158-Port d’Andratx. Illes Balears. España. E-mail: friera@dgpesca.caib.es \\ 2 SEAMASA. C/ Foners 10, 07006-Palma de Mallorca. Illes Balears. España. \\ ${ }^{3}$ Direcció General de Pesca i Cultius Marins. Foners 10, 07006. Palma de Mallorca. Illes Balears. España.
}

\begin{abstract}
SUMMARY: Species composition, size range and some behavioral notes about drifting flotsam associated fish of the Balearic Islands are presented, and more detailed observations on Seriola dumerili, Naucrates ductor, Coryphaena hippurus and Scomberesox saurus are also given. 25 fish species belonging to 18 families were identified, 12 of these species and the individuals of the family Mugilidae were recorded for the first time associated with floating objects in the western Mediterranean. Most of the specimens collected were juveniles, which suggests the importance of floating objects as a nursery, and thus in the recruitment and redistribution of fishes. Analisis of two drift floating material samples show that objects of anthropogenic origin were most abundant $(83.5 \%$ and $63.5 \%)$ and suggests that at present, human refuse may have taken over the role of the floating remains of marine plants for fishes in the western Mediterranean pelagic environment.
\end{abstract}

Key words: Juvenile fish, drifting flotsam, Balearic Islands, western Mediterranean.

\section{INTRODUCTION}

Several hypotheses have been put forward to explain the association of fishes with floating objects, the most important being: to enhance conditions for feeding, to provide shelter from predators and to provide a substratum in the homogeneous pelagic environment (Gooding and Magnuson, 1967; Hunter and Mitchell, 1967; Kingsford, 1992).

In the Mediterranean Sea the only available studies on fishes associated with floating objects have been mainly based on commercial catches (Massutí and Reñones, 1994) or visual censuses (Relini et al., 1992) under fish aggregation

\footnotetext{
*Received December 15, 1997. Accepted February 2, 1999.
}

devices. Commercial catches provide relatively big fishes (generally greater than $15 \mathrm{~cm} \mathrm{TL}$ ) due to seasonal fishing (from late August to early December) and the mesh size employed, and few data about little fishes were provided by visual census (Relini et al., 1992). Accordingly we have little or marginal information about little fishes associated with drifting flotsam. This study deals with species composition and size distribution of the drifting flotsam associated fishes in the Balearic Islands. Some seasonal patterns and behavioral observations are also presented.

At the moment little or nothing is known about the nature or types of drifting material in the western Mediterranean. We report preliminary data about the nature of these objects. 


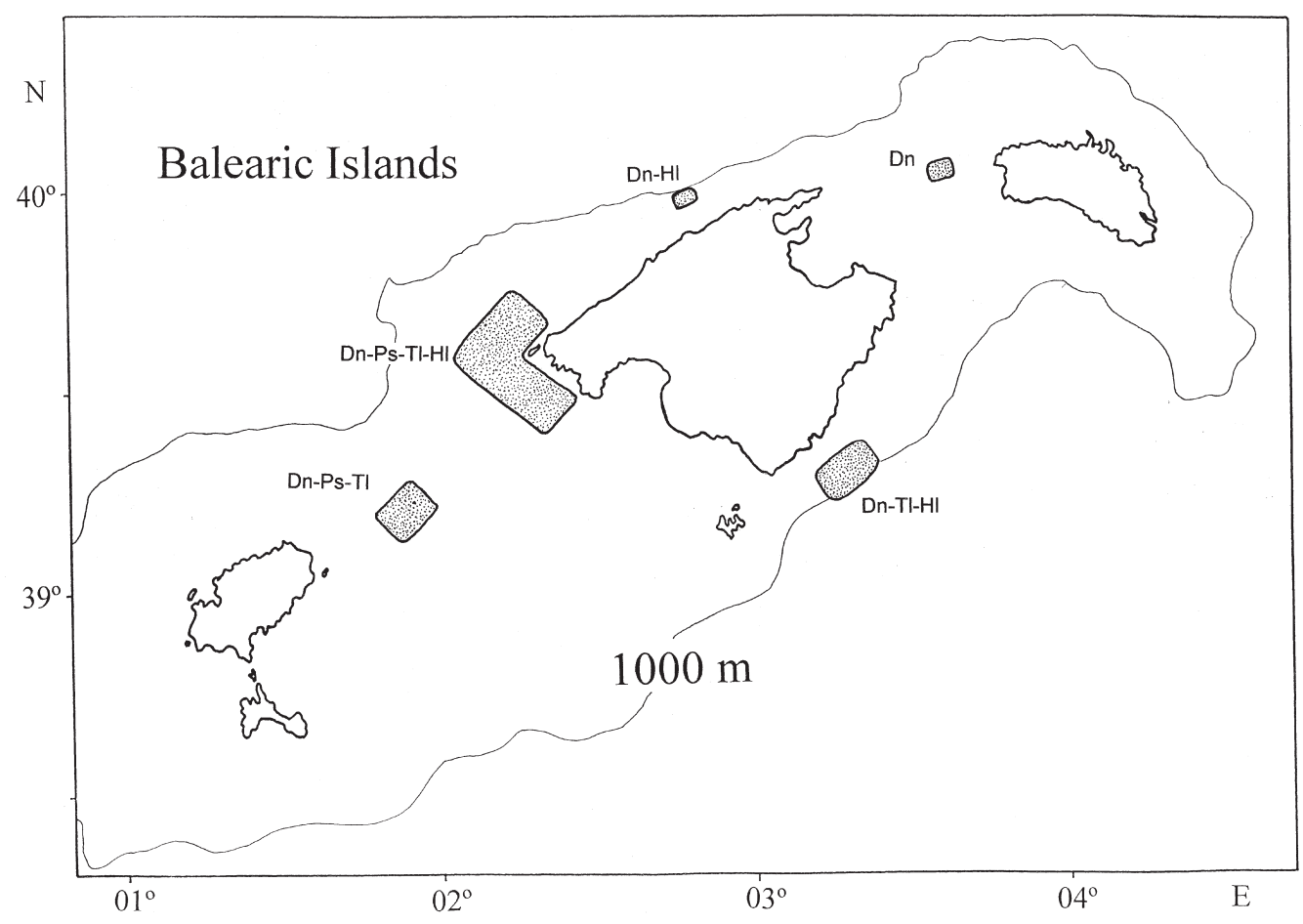

FIG. 1. - Map of the Balearic Islands with the sampling areas and the gears used (Dn: dip net; Ps: purse seine; Tl: trolling line; Hl: hand line).

\section{MATERIAL AND METHODS}

This study was made in the framework of a project carried out between 1990 and 1996 with the aim of obtaining Seriola dumerili juveniles for aquaculture research. As this work was not part of the main study, the sampling was sometimes out of order although it provides some unpublished data and observations that we consider to be of interest. Offshore samples and observations were carried out from July to November but data from February, May and June were also available. The sampling areas were situated in neritic and oceanic waters of the Balearic Islands in a depth range of 50 to $1100 \mathrm{~m}$ (Fig. 1).

The capture of specimens was based on a series of dip netting samples, supplemented by purse seine, trolling line and hand line collections (Table 1) when fishes were larger than $10-15 \mathrm{~cm}$. The drifting floating objects (algae, seaweeds, gelatinous plankton, logs, marine bird feathers, plastics, etc.) were removed with a $50 \mathrm{~cm}$ diameter dip net with a $2 \mathrm{~mm}$ mesh size to catch the small-sized fishes which were sometimes associated with them.

The individuals captured were measured (total length, to the nearest $\mathrm{mm}$ ) and weighed (to the nearest $0.01 \mathrm{~g}$ ) in the laboratory.
Seriola dumerili juveniles were collected from August to October in littoral waters off the west of Mallorca in order to find the size and date when fingerlings change their offshore (epipelagic) habits for their littoral (epibenthic) ones. These littoral catches were mainly made with a net trap called "moruna" (Llabrés and Martorell, 1984) with a $1.5 \mathrm{~cm}$ mesh size, though trolling line and gillnets were also used.

In two surveys (15/07/95 and 27/10/96) in which numerous drifting objects were found in the west of Mallorca, the type of materials was evaluated: all floating objects in an area of about $1000 \times 50 \mathrm{~m}$ (at 90 and $100 \mathrm{~m}$ depth approximately) were removed and classified in order to determine the percentages of natural (algae, neustonic invertebrates, feathers, logs etc.) and artificial materials (human refuse).

TABLE 1. - Number (N) of samples with captures per gear and season.

\begin{tabular}{lrrrrr}
\hline GEAR & N & Spring & Summer & Autumn & Winter \\
\hline Dip net & 349 & 26 & 191 & 102 & 28 \\
Purse seine & 14 & - & 5 & 9 & - \\
Hand line & 15 & 1 & 3 & 10 & 1 \\
Trolling line & 12 & - & - & 12 & - \\
TOTAL & 390 & 27 & 199 & 133 & 29 \\
\hline
\end{tabular}


TABLE 2. - Family and species collected and gear used (Dn: dip net; Ps: purse seine; Hl: hand line) in the capture of drifting flotsam associated fishes in the Balearic Islands.

\begin{tabular}{|c|c|c|}
\hline FAMILY & SPECIES & GEAR USED \\
\hline Apogonidae & Apogon imberbis (Linnaeus, 1758) & Dn \\
\hline Balistidae & Balistes carolinensis Gmelin, 1789 & $\mathrm{Dn} ; \mathrm{Ps} ; \mathrm{Hl}$ \\
\hline \multirow[t]{3}{*}{ Blenniidae } & Lipophrys trigloides Valenciennes, 1836 & $\mathrm{Dn}$ \\
\hline & Parablennius sanguinolentus Pallas, 1811 & $\mathrm{Dn}$ \\
\hline & Unidentified species & $\mathrm{Dn}$ \\
\hline Caproidae & Capros aper (Linnaeus, 1758) & $\mathrm{Dn}$ \\
\hline \multirow[t]{5}{*}{ Carangidae } & Naucrates ductor (Linnaeus, 1758) & $\mathrm{Dn} ; \mathrm{Ps} ; \mathrm{Tl} ; \mathrm{Hl}$ \\
\hline & Seriola dumerili (Risso, 1810) & $\mathrm{Dn} ; \mathrm{Ps} ; \mathrm{Tl} ; \mathrm{Hl}$ \\
\hline & Trachurus mediterraneus (Steindachner, 1868) & Dn \\
\hline & Trachurus picturatus (T. E. Bowdich, 1825) & $\mathrm{Dn}$ \\
\hline & Trachurus trachurus (Linnaeus, 1758) & $\mathrm{Dn}$ \\
\hline Centracanthidae & Centracanthus cirrus Rafinesque, 1810 & $\mathrm{Dn}$ \\
\hline \multirow[t]{2}{*}{ Centrolophidae } & Schedophilus medusophagus Cocco,1839 & $\mathrm{Hl}$ \\
\hline & Schedophilus ovalis (Cuvier, in Cuv. Val. 1833) & Ps \\
\hline Coryphaenidae & Coryphaena hippurus Linnaeus, 1758 & Dn;Ps;Tl \\
\hline Gadidae & Gaidropsarus mediterraneus Linnaeus, 1758 & Dn \\
\hline Lobotidae & Lobotes surinamensis (Bloch, 1790) & Ps \\
\hline Mullidae & Mullus surmuletus Linnaeus, 1758 & $\mathrm{Dn}$ \\
\hline Mugilidae & Unidentified species & $\mathrm{Dn}$ \\
\hline Nomeidae & Psenes pellucidus Lütken, 1880 & $\mathrm{Dn}$ \\
\hline Scomberosocidae & Scomberesox saurus (Walbaum, 1792) & Ps \\
\hline Scombridae & Thunnus thynnus (Linnaeus, 1758) & Ps;Tl \\
\hline Serranidae & Polyprion americanus (Shneider, 1801) & $\mathrm{Dn} ; \mathrm{Ps} ; \mathrm{Hl}$ \\
\hline \multirow{3}{*}{ Sparidae } & Diplodus puntazzo (Gmelin, 1789) & Dn \\
\hline & Pagellus acarne (Risso,1826) & $\mathrm{Dn}$ \\
\hline & Pagrus pagrus Linnaeus, 1758 & $\mathrm{Dn}$ \\
\hline Syngnathidae & Syngnathus typhle Linnaeus, 1758 & $\mathrm{Dn}$ \\
\hline
\end{tabular}

TABLE 3. - Number $(\mathrm{N})$, size range and month of capture of drifting floating object associated fishes.

\begin{tabular}{|c|c|c|c|}
\hline Species & $\mathrm{N}$ & $\begin{array}{l}\text { Size range } \\
\text { T L (cm) }\end{array}$ & Month of capture \\
\hline Apogon imberbis & 4 & $1.8-2.2$ & 10 \\
\hline Balistes carolinensis & 17 & $7.3-27.7$ & $7-8-9-10$ \\
\hline Blenniidae unidentified & 5 & $1.6-2.6$ & $5-6-7$ \\
\hline Capros aper & 3 & $3.3-3.5$ & 2 \\
\hline Centracanthus cirrus & 2 & $5.7-5.9$ & 2 \\
\hline Coryphaena hippurus & 189 & $3.6-72.5$ & $8-9-10-11$ \\
\hline Diplodus puntazzo & 8 & $1.5-2.2$ & 10 \\
\hline Gaidropsarus mediterraneus & 4 & $3.3-3.5$ & $5-6$ \\
\hline Lipophrys trigloides & 3 & $2.0-2.4$ & 5 \\
\hline Lobotes surinamensis & 1 & 56.3 & 9 \\
\hline Mugilidae unidentified & 111 & $1.5-2.9$ & $2-10-11$ \\
\hline Mullus surmuletus & 63 & $3.7-6.5$ & $6-7$ \\
\hline Naucrates ductor & 197 & $2.3-37.8$ & $2-5-7-8-9-10-11$ \\
\hline Pagellus acarne & 105 & $1.2-4.1$ & $5-6-10-11$ \\
\hline Parablennius sanguinolentus & 5 & $2.7-2.8$ & $5-6$ \\
\hline Polyprion americanus & 7 & $29.4-46.0$ & $5-7-8-9$ \\
\hline Psenes pellucidus & 1 & 16.6 & 11 \\
\hline Scomberesox saurus & 27 & $24.1-31.1$ & 10 \\
\hline Schedophilus medusophagus & 1 & 19 & 6 \\
\hline Schedophilus ovalis & 3 & $44-49.6$ & $9-10$ \\
\hline Seriola dumerili & 145 & $1.3-31.3$ & $7-8-9-10$ \\
\hline Pagrus pagrus & 9 & $2.4-2.8$ & $5-6-7$ \\
\hline Syngnathus typhle & 4 & $2.0-3.9$ & 10 \\
\hline Thunnus thynnus & 34 & $25.8-41.6$ & $9-10-11$ \\
\hline Trachurus spp. & 127 & $1.0-11.5$ & $2-5-6-7-8-9-10$ \\
\hline
\end{tabular}

\section{RESULTS}

Fishes belonging to 18 families were caught and 25 species have been recognised associated with drifting flotsam. In addition, specimens of the fami- lies Mugilidae and Blenniidae could not be identified at species level (Table 2).

All the individuals of Apogon imberbis, Capros aper, Centracanthus cirrus, Diplodus puntazzo, Polyprion americanus, Balistes carolinensis, 

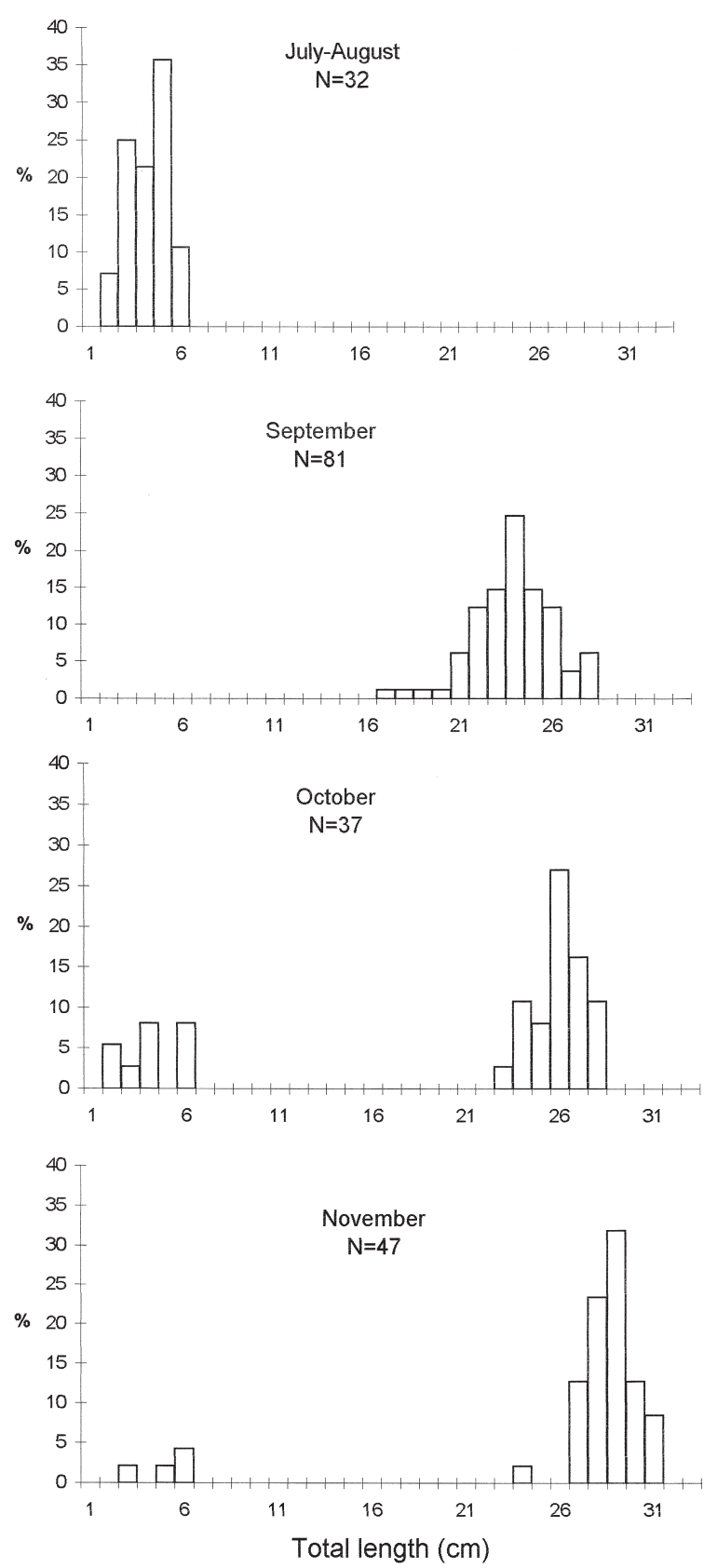

FIG. 2. - Size frequency distributions of Naucrates ductor from July to November.

Gaidropsarus mediterraneus, Mullus surmuletus, Pagellus acarne, Pagrus pagrus, Syngnathus typhle, the mullets and the blennies were presettled forms of benthic fishes, and generally showed narrow size ranges (Table 3). Only individuals of Balistes carolinensis, Naucrates ductor, Coryphaena hippurus, Scomberesox saurus and the Lobotes surinamensis specimen were adults or mature fishes.

Two fingerlings of Coryphaena hippurus (3.6 and $8 \mathrm{~cm} \mathrm{TL}$ ) were collected in neritic waters 0.5
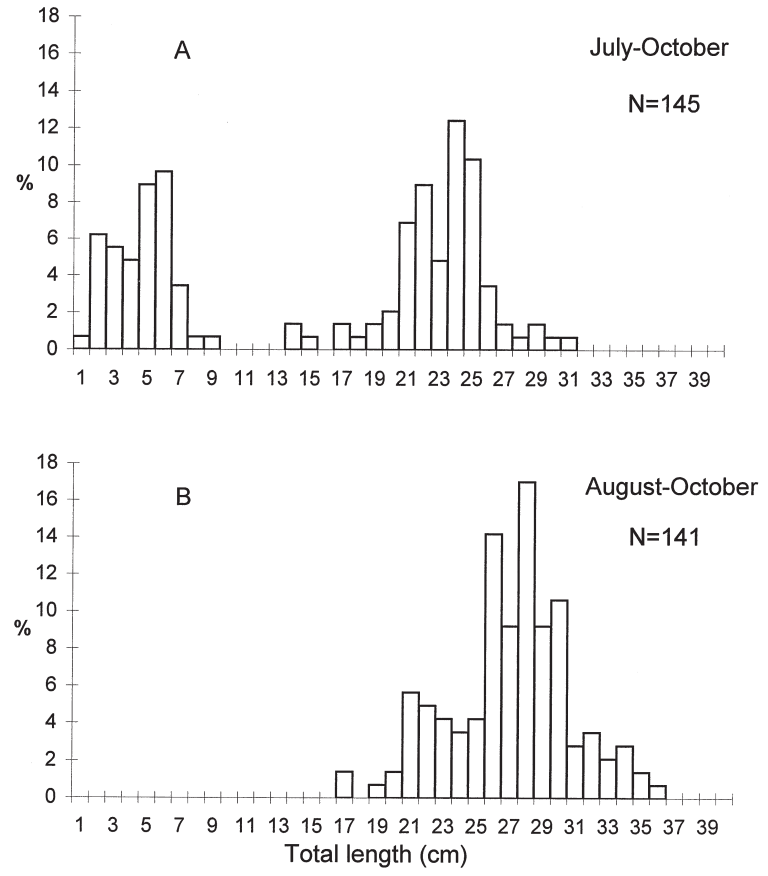

FIG. 3. - Size frequency distributions of Seriola dumerili. A) Fishes caught in offshore waters and B) Fishes caught in onshore waters.

and 3 nautical miles from the west coast of Majorca at 60 and $80 \mathrm{~m}$ depth (November 1990 and November 1991). In both cases, the fishes were caught some meters away from drifting objects (about $50 \mathrm{~m}$ of a small floating $\log$ and about $35 \mathrm{~m}$ from a plastic bag respectively) but not directly associated with them. In the capture, the fishes remained absolutely immobile, slightly inclined on one side with the dorsal and anal fins extended.

Regular presence of small ( $<10 \mathrm{~cm}$ TL) Naucrates ductor was observed only in two periods of the year: July-August and October-November (Fig. 2).

Scomberesox saurus was caught only in nocturnal purse seine hauls surrounding drifting objects, but was usually observed during the day in the open sea without apparent connection to floating objects.

Ontogenetic changes in the aggregative behaviour of juvenile Seriola dumerili were observed, and three stages were detected. Fishes smaller than $10-15 \mathrm{~cm}$ TL have a strong affiliation with floating objects, moving very close around them in little schools (normally less than 10 fishes); fishes larger than $10-15 \mathrm{~cm}$ TL to approximately $30-35 \mathrm{~cm}$ TL continue to be associated with the flotsam, but form larger schools (up to hundreds of fishes) and move considerable distances (50 m or more) from the floating object to hunt actively. These changes are gradual, and the distances and movements 
TABLE 4. - Results in number (N) and percentage (\%) of the types of materials found as drifting flotsam.

\begin{tabular}{lrrrrr}
\hline & \multicolumn{4}{c}{ Date } \\
& \multicolumn{1}{c}{$15 / 07 / 95$} & \multicolumn{2}{c}{$27 / 10 / 95$} \\
Material & $\mathrm{N}$ & $\%$ & $\mathrm{~N}$ & $\%$ \\
& & & & \\
\hline \multirow{2}{*}{ Anthropogenic materials } & 106 & 83.5 & & 61 & 63.5 \\
Algae and seaweed & 8 & 6.3 & 11 & 11.5 \\
Wood and terrigenous plants & 12 & 9.4 & 16 & 16.7 \\
Feathers & 1 & 0.8 & 5 & 5.2 \\
Neustonic invertebrates & 0 & 0 & 3 & 3.1 \\
TOTAL & 127 & 100 & 96 & 100 \\
& & & & & \\
\hline
\end{tabular}

increase as the fishes grow. Finally, the fishes change their pelagic-oceanic habits for a coastal one. Figure 3 show length-frequency distributions between offshore (A) and littoral fishes (B): the smallest epibentic individuals caught onshore had $17 \mathrm{~cm}$ TL and appeared from August, whereas pelagic young were observed during the July-October period.

A high percentage of the drifting objects analysed were artificial (of anthropogenic origin): $83.5 \%$ in July 1995 and $63.5 \%$ in October 1996 (Table 4).

\section{DISCUSSION}

Nearly all the captured fishes were juveniles or larval postflexion forms (sensu Kendall, Ahlstrom and Moser in Blaxter, 1988). From the 25 identified species, 20 were caught with the dip net, (generally the smallest specimens, see Table 1). Most of them (Apogon imberbis, Diplodus puntazzo, Lipophrys trigloides, Parablennius sanguinolentus, Gaidropsarus mediterraneus, Mullus surmuletus, Pagellus acarne, Pgrus pagrus, Siyngnatus typhle, Capros aper, Centracanthus cirrus and the Mugilidae) had never been described in association with drifting objects in the Mediterranean. The use of a dip net ensures that the species caught have a high level of association with the drifting objects, though it does not mean that these species can only live in the open sea in association with floating objects.

Tough Coryphaena hippurus juveniles are very abundant from August to November in neritic and oceanic waters, the catches of dolphinfish larvae and fingerlings are very rare in the Balearic Islands, where Lozano Cabo (1961) reported the capture of 2 specimens (about $10 \mathrm{~cm} \mathrm{TL}$ ) and Alemany and Massuti (1998) collected four early larval stages. The behaviour observed by us and that described by Gibbs and Collette in Palko et al. (1982), who observed that very small specimens look like feathers when remaining immobile with the fins extended, indicate that when dolphinfish fingerlings are very young they have a different behaviour from that of the bigger juveniles $(>15 \mathrm{~cm})$ : they are solitary and do not normally show strong association with flotsam. The rarity of the fingerlings might be due to their "non-aggregative and non-gregarious behaviour", because it contributes to the difficulty of finding the little fishes in the ocean.

Two recruiment episodes were observed in $\mathrm{Nau}$ crates ductor in the study area: one in July-August and one in October-November (Fig. 2). Many authors suggest that pilotfish juveniles are epipelagic and live associated with floating objects, while the adults live associated with sharks, big rays and other marine animals (SmithVaniz, 1986; Bauchot, 1987; Brito, 1991), reaching a maximum total length of $70 \mathrm{~cm}$ (Smith Vaniz 1986). However, Wheeler (1978) states that young fishes school in small groups and live associated with great rays, sharks, turtles, sailships or wooden floating objects and that the adults are solitary. In our observations the largest specimens observed never exceeded $37 \mathrm{~cm}$ total length and fishes can reach sexual maturity when still aggregated with drifting objects. We believe Naucrates ductor join sharks and other big fishes or marine animals as soon as they can, regardless of size: Cousteau and Dumas (1963) observed and photographed a young N. ductor of 6-7 cm associated with a Carcharinus longimanus in the southwestern Atlantic. The association with sharks or other marine animals may be dependent on their presence or availability. The living hosts tend to remain in favourable environments while drifting objects may arrive at unfavourable sites or may stranded on the coast, where pilotfish are very conspicuous and could succumb to predators (in Ibiza, N. ductor are used as live bait to fish greater amberjack in inshore waters, and we have observed large Lichia amia hunting pilotfishes nearshore). On the other hand, Smith-Vaniz (1986) thinks that the association with sharks may be related to trophic motives: feeding on scraps and ectoparasites of the hosts.

In our collections Seriola dumerili specimens associated with floating objects reached a size of $31.3 \mathrm{~cm}$ TL, which approximately coincides with that observed by Massutí and Reñones (1994). The three stages detected in aggregative behaviour are 
probably related to changes in feeding habits, as can be inferred from Badalamenti et al. (1995), who observed three different size groups related to feeding behaviour of juveniles from 2.5 to $29.7 \mathrm{~cm} \mathrm{SL}$. With respect to the appearance of epibenthic juveniles in littoral waters, Lo Bianco (1909) found fishes of similar size to those caught by us (Fig. 3 B) in the same month. Therefore, it seems that in the western Mediterranean the change of offshore pelagic habits for epibenthic ones in littoral waters starts in August and at a size close to $15 \mathrm{~cm}$ TL when fishes adquire their final feeding habits.

Scomberesox saurus was only caught in two nocturnal purse seine hauls but it was normally observed during the day in the open sea without apparent connection to floating objects. This may indicate that the catches were fortuitous, but $S$. saurus may have a similar behaviour to Coryphaena hippurus, which schools at night under floating objects (Lozano Cabo, 1961). This behaviour may contribute to the fact that $S$. saurus is one of the main preys of $C$. hippurus from Mallorca (Massutí, 1997). Furthermore, association with drifting seaweeds has been mentioned by Safran and Omori (1990) for other species of the family Scomberosocidae, in Japanese waters.

The abundance of most of the fauna associated with floating objects is strongly dependent on season (Roundtree, 1990). Though samples were not taken in all months (see Table 3) our results seem to indicate that the presence of small fishes is related to their spawning season according to Bauchot (1987) or Tortonese (1975); only the data on catches of Capros aper and Centracanthus cirrus show divergences with their spawning season which are difficult to explain. In addition many benthic or epibenthic species presented only small individuals and showed an extremely restricted size range, so we can infer that they remain associated with floating objects for a short time before they live in their final native environment. In our collections, other fishes reaching relatively large sizes were presettled individuals of bentic fishes (Poliprion americanus, Ba-listes carolinensis, and Lobotes surinamensis); these large sizes are probably determined by the fast growth and the long residence associated with flotsam. Evidence of fast growth exists in aquacultural trials for P. americanus and Balistes carolinensis (F. Riera, unpublished data). L. surinamensis and B. carolinensis can remain for long periods associated with flotsam, and some of our observations support this opinion: the L. surina- mensis specimen was a large post-spawning female, and B. carolinensis specimens larger than $20 \mathrm{~cm}$ were caught in July, in the spawning season of the species (Tortonese, 1986). It would not be logical to think that settled specimens return to pelagic life.

Although other seas have constant concentrations of drifting floating objects with seaweeds predominating (Parin and Fedoryaco, 1992), drifting objects of anthropogenic origin are more abundant than drift floating algae in the Balearic Islands waters (Table 4). The most common algae observed drifting in our area were Cystoseira spp., probably due to their buoyancy and seasonal deciduous fronds (Cabioc'h et al., 1992). The presence of these algae is in decline in the Mediterranean (Bellan, 1985) and some species reach very high percentages $(80 \%)$ of disappearance (Bacescu, 1985); this is also true in the Balearic Islands for Cymodocea nodosa and Zostera nolti, marine seagrasses, which float when they are cut off. It is thus feasible to consider that anthropogenic objects may partly replace marine floating plants for fishes in the Mediterranean pelagic environment. Kingsford (1992) suggests three consequences of drift algae movement on fish distribution: (1) by moving into an area drift algae may quickly change the distribution of some fish types, especially those that are well dispersed in open water; (2) if fish stay with drift algae for some time, the movements of the algae will determine those of the fish; (3) where algae often drift towards shore, this may result in increased recruitment rates of fish found nearshore as adults. These points may be extrapolated to drift anthropogenic objects and therefore human refuse contributes to the redistribution of fishes.

In short, we conclude: (i) up to now there existed a gap in the knowledge of small fish communities associated with floating objects in the Mediterranean Sea because attention had focused mainly on relatively large specimens ( $>15 \mathrm{~cm}$ aproximately); (ii) the majority of small fish we found (A. imberbis, Diplodus puntazzo, Centracanthus cirrus, Lipophrys trigloides, Parablennius sanguinolentus, Gaidropsarus mediterraneus, Mullus surmuletus, Pegellus acarne, Pagrus pagrus, Syngnathus typhle) were benthic species with narrow size ranges that probably remain associated with floating objects for a short time; (iii) floating objects may have a significant impact as a nursery, and consequently on the recruitment and redistribution of pelagic and nonpelagic fishes. 


\section{REFERENCES}

Alemany, F. and E. Massutí. - 1998. First record of larval stages of Coryphaena hippurus (Pisces: Coryphaenidae) in the Mediterranean Sea. Sci. Mar., 62(1-2): 181-184.

Bacescu, M. - 1985. The effects of the geological and phyco-chemical factors on the distribution of marine plants and animals in the Mediterranean. In: M. Moraitou-Apostolopoulou and V. Kiortsis (eds.), Mediterranean Marine Ecosystems. NATO conference series. I, Ecology; vol. 8, pp. 195-212. Plenum Press, New York.

Badalamenti, F., G. D'Anna, L. Lopiano, D. Scilipoti and A. Mazzola. - 1995. Feeding habits of young-of-the-year greater amberjack Seriola dumerili (Risso, 1810) along the N/W Sicilian Coast Sci.Mar., 59(3-4): 317-323.

Bauchot, M. L. - 1987. Poissons osseaux. In: W. Fischer, M.L. Bauchot and M. Schneider (eds.), Fiches FAO d'identification des espèces pour les besoins de la pêche. Rev 1, Méditerranée et Mer Noire. Zone de pêche 37. Tome II, pp 891-1421. FAO. Roma.

Bellan, G. - 1985. Effects of pollution and man-made modifications on marine benthic communities in the Mediterranean: a review In: M. Moraitou-Apostolopoulou and V. Kiortsis (eds.), Mediterranean Marine Ecosystems. NATO conference series. I, Ecology; vol. 8, pp. 163-194. Plenum Press, New York.

Blaxter, J.H.S. - 1988. Pattern and variety development. In: W.S Hoar and D.J. Randall (eds.), Fish physiology, vol. XI, part A, pp. 1-58. Academic Press, San Diego.

Brito, A. - 1991. Catálogo de los peces de las Islas Canarias. Francisco Lemus, editor. La Laguna. $230 \mathrm{pp}$

Cabioc'h, J., J.Y. Flo'h, A. Le Toquin, Ch.F. Boudouresque, A Meinesz and M. Verlaque. - 1992. Guide des algues des Mers d'Europe. Delachaux et Niestlé, Paris.

Cousteau, J.Y. and F. Dumas. - 1963. El mundo silencioso. Editorial Exito S. A. Barcelona.

Gooding, R.M. and J.J. Magnuson. - 1967. Ecological significance of a drifting object to pelagic fishes. Pacif. Sci., 21: 486-497.

Grau, A. - 1992. Aspectos histológicos, ciclo reproductor y principales procesos patológicos de Seriola dumerili, Risso 1810 (Carangidae). Ph. D. thesis. Universitat Autónoma de Barcelona.

Hunter, J.R. and C.T. Mitchell. - 1967. Association of fishes with flotsam in the offshore waters of Central America. Fish. Bull. U.S. 66: 13-29 .

Kingsford, M.J. - 1992. Drift algae and small fish in coastal waters of northeastern New Zealand. Mar. Ecol. Prog. Ser., 80: 41-55

Lo Bianco, S. - 1909. Notizie biologiche riguardanti spezialmenti il periodo di maturita sessuale degli animali del golfo di Napoli. Mitt. Zool. Stn. Neapel, 19: 513-761.

Lozano Cabo, F. - 1961. Biometría, Biología y Pesca de la Lampuga (Coryphaena hippurus L.) de las islas Baleares. Mem. R. Acad. Cienc. Fís. Exact. y Nat., Serie de Ciencias Naturales, 21: $1-93$.

Llabrés, M. and M. Martorell. - 1984. La pesquería de artes menores. Comunidad Autónoma de las Islas Baleares, Ed. Palma.

Massutí, E. - 1997. Biology of Coryphaena hippurus Linnaeus, 1758 (Pisces: Coryphaenidae) in the Western Mediterranean, $\mathrm{Ph}$. D. thesis, Univ. Illes Balears.

Massutí, E. and O. Reñones. - 1994. Observaciones sobre la comunidad de peces pelágicos asociados a objetos flotantes en aguas oceánicas de Mallorca. Bol. Inst. Esp. Oceanogr. 10(1): 81-93.

Matsumoto, W.M., T.K. Kazama and D.C. Aasted. - 1981. Anchored fish aggregating devices in Hawaiian waters. Mar. Fish. Rev., 43(9): 1-13.

Parin N.V. and R.I. Fedoryaco. - 1992. Pelagic fish communities around floating objects in the open ocean. In: IATTC, Objects flottants et thons. Presenté a la $12^{\text {ème }}$ Semaine des Pêches. 5 pp. Açores.

Palko, B.J., G.L. Beardsley and W.J. Richards. - 1982. Synopsis of the Biological Data on Dolphin-Fishes, Coryphaena hippurus Linnaeus and Coryphaena equiselis Linnaeus. FAO Fisheries Synopsis, 30: 28 pp.

Relini, M., L. Orsi-Relini and G. Relini. - 1994. An offshore buoy as a F.A.D. in the Mediterranean. Bull. Mar. Sci., 55(2-3): 1099-1105.

Rountree, R. A. - 1990. Community structure of fishes attracted to shallow water fish aggregation devices off South Carolina, U.S.A. Environmental Biology of Fishes, 29: 241-262.

Safran, P. and M. Omori. - 1990. Some ecological observations on fishes associated with drifting seaweed off Tohoku coast. Japan. Mar. Biol., 105: 395-402.

Smith-Vaniz, W. F. - 1986. Carangidae. In: P.J.P. Whitehead, M.L. Bauchot, J.C. Hureau, J. Nielsen and E. Tortonese (eds.), Fishes of the North-eastern Atlantic and the Mediterranean. Vol. II, pp. 815-844. UNESCO, Paris.

Tortonese, E. - 1975. Osteichthyes (Pesci ossei). Parte Seconda. Fauna d'Italia vol. XI. Edizione Calderini, Bologna.

Tortonese, E. - 1986. Balistidae In: P.J.P. Whitehead, M.L. Bauchot, J.C. Hureau, J. Nielsen and E. Tortonese (eds.), Fishes of the North-eastern Atlantic and the Mediterranean. Vol. III, pp.1335-1340. UNESCO, Paris

Wheeler, A. - 1978. Key to the fishes of Northern Europe. Warne Publishers, London. 